\title{
Chapter 10 \\ Employee Representatives in Portugal. How are they Perceived and what are the Expectations by Employers?
}

\author{
Ana M. Passos and Vanessa Russo
}

\subsection{The Historical Context of the Labor Movement in Portugal}

The evolution of the labor movement in Portugal follows the evolution verified in other countries, bearing in mind a more delayed industrialization. The labor movement started in 1853 with the foundation of the "Centro Promotor do Melhoramento da Classe Laboriosa". The first strikes occurred in 1872 and, at the end of the XIX century, the workers' organizations multiplied until there were 392 workers' organizations registered in 1882. In 1914, the first Confederation was founded that later changed its name to Confederação Geral dos Trabalhadores Portugueses (CGTP) (Stoleroff 2000). With the dictatorship (1933-1974), the existing unions were dissolved and a corporative union was established, with absolute state control.

The labor movement in Portugal can be divided into three phases in the period between 1933 and 1987: (1) corporative phase-referring to the period of the dictatorship and integrated within the national policy and subjected to a strict control and severe restrictions on their activity; (2) unitary phase-starting with the beginning of 1974 until the elaboration of the constitutional document in 1976, which is characterized by a strong support for the ideals defended by the Portuguese Communist Party. With the Carnation Revolution of 25th April of 1974, the Inter-union (CGTP-In) appeared as the only organization capable of covering almost all corporate unions; (3) Union pluralism - consecrated with the Constitution of 1976 and the beginning of the União Geral de Trabalhadores (UGT), aggregating the union tendencies that were not in harmony with the orientation and philosophy of CGTPIN (Noronha 1993). The crystallization of political antagonisms within the labor movement following the 25th of April, resulted in a Portuguese labor movement

\author{
A. M. Passos $(\bowtie) \cdot$ V. Russo \\ Instituto Universitário de Lisboa (ISCTE-IUL), Lisbon, Portugal \\ e-mail: ana.passos@iscte.pt \\ V. Russo \\ e-mail: vanessa.russo87@gmail.com \\ (C) The Author(s) 2015
}

M. Euwema et al. (eds.), Promoting Social Dialogue in European Organizations,

Industrial Relations \& Conflict Management 1, DOI 10.1007/978-3-319-08605-7 10 
divided between these two ideologically and politically opposed confederations and a cohort of independent unions (Stoleroff 2000).

In 1992 the Portuguese economy converged with the general European recession. There was a significant decline in employment of $1 \%$, and by 1993 there was a negative growth of $2 \%$. The decline continued until 1995. The annual declines in salaried employment were greater in this period and in 1995 Portugal arrived at one of the highest rates of unemployment (Stoleroff 2000). This increase of unemployment in the context of continuing restructuring, contributed to a general decrease of union strength. Strike frequency declined with the downward economic curve. The decline in strikes was also coincident with the institutionalization of tripartite bargaining and it could be argued that conflict was channeled to social dialogue and that Portuguese neo-corporatism had been successful. However, this was not the case. The decline in strikes was an indicator of the decrease in the unions' ability to mobilize the workers that resulted from the crisis (Stoleroff 2000).

The late 1990s and the beginning of the 2000s were marked by a lagging economy where Portugal failed to catch up with the EU average. Public expenditure rose to unsustainable levels and the number of public workers reached unprecedented proportions. State-funded and supported construction projects (Expo 98 World Fair in Lisbon, the 2004 European Football Championship) proved to have little positive effect in fostering sustainable growth. The short-term impact of these major investments was exhausted by the end of 2000, which led to increased unemployment and a downturn in the economy (Rosa 2011).

Nowadays, union density in Portugal is below $20 \%$ and has been decreasing constantly. There are higher levels in public services and in some larger companies (Census 2011). The two main union confederations in Portugal-CGTP and UGT - have been losing members. In addition, there are a number of smaller unions outside the main confederations. Today CGTP, UGT and unaffiliated unions together may have between 700,000 and 800,000 members, with CGTP counting for about two thirds of the organized workforce. Regarding their collective bargaining, the percentage of employees covered by collective agreements was over $90 \%$ of the workforce in the private sector in 2010 (Quadros de Pessoal 2009). However, from 2010 until the end of 2013 there has been a dramatic decrease of the number of workers covered by collective agreements and also a reduction of collective agreements instruments. According to a recent report from the Ministry of Solidarity, Employment and Social Security the number of workers covered by collective agreements decreased $86 \%$ from 2010 to the second semester of 2013 .

The main channels of employee representation in Portugal at the workplace level are the workers' councils (WC), shop stewards and TU committees, and the workers' representatives for safety and health. Their competences and procedures are regulated by the Labor Code. WCs and TUs are protected by constitutional law (Dornelas et al. 2006). The WCs are elected by all employees at a company. The number of members varies between two (for organizations with less than 50 employees) and 11 (for organizations with more than 1000 employees) according to the number of workers in the company. The WCs have information and consultative rights regarding the processes of restructuring, in setting up plans and reports and 
regarding any changes in working conditions. The shop stewards are elected only by the union members in the organizations. TUs have the exclusive legal right to call for strikes and to sign collective agreements. In companies without WCs the union committee may exercise their rights concerning consultation and information (Dornelas et al. 2006). Usually, the elections of the shop stewards take place every 2 years in Portugal. Relations between WC and shop stewards can vary a lot, from cooperative to competitive.

At the beginning of 2011, the public finance crisis in Portugal escalated. In April, the socialist government called for foreign help to avoid a default situation. On the 3rd of May 2011, the Socialist government signed a "Memorandum of Understanding on Specific Economic Policy Conditionality" that resulted from the negotiations with the troika (i.e. refer to the presence of the European Union, European Social Bank and the International Monetary Fund in the country). The memorandum constituted the "framework for the further economic, social and employment policy of the new liberal-conservative coalition government" (Reinhard 2013). The document imposed drastic austerity measures that contributed to the economic downturn. In 2011, GDP decreased by $1.6 \%$ - a negative trend that accelerated in 2012. Inflation rose to $3.6 \%$, whereas in previous years it had been below the average of the Eurozone $(0.9 \%$, in 2009 , and $1.4 \%$ in 2010$)$. The unemployment rate reached $14 \%$ in 2011 while youth unemployment (15-24 years) soared to 35.6\% (Reinhard 2013).

\subsection{The Current Situation of ERs}

In this section we summarize the most relevant indicators referred to by the employers in the interviews. The information is structured by the principal themes of the interview (attitudes and competencies, trust and relationship among ERs and management and labor relations in organizational conflicts).

\subsubsection{Attitudes and Competencies}

The qualitative results of this study clearly indicate that Portuguese managers perceive a lack of competence and innovation regarding ERs. The main concerns of employers regarding the ERs' attitudes and competencies are:

Need for Professionalism Most employers said that ERs need to be less ideological and more professional. Regarding this concern, most employers suggested some training in problem solving, but directed to effective solutions for the problem without "ideological contamination".

The ideological orientation that shapes the profile of ERs in Portugal is characterized by the belief that the organization wants to harm workers, making an alliance between these two parts very difficult. However, there have been some changes in profile regarding ERs. Within WCs, there is a less ideological orientation and, in the employers' view, more proximity to the reality of the organization. 
I would live very well with a model where there was a direct relationship with a large committee of workers' representatives, which includes workers with different types of contracts, without the need for unions. (HR manager, production sector)

ERs are Decontextualized There is a general opinion that ERs, mostly the shop stewards, are very distant from the reality of the organization. According to the respondents, this is due to the lack of renewal of the staff and by the fact that most ERs only appear in the organization when it is time for negotiations or elections. This low active participation by the shop stewards results in proposals that are characteristically inadequate, when bearing in mind the reality of the organization.

Unions should realize what is the current life of organizations, regardless of the industry sector. They should understand the changes that companies have faced in the last decade. People in unions are not aware of this new reality. (HR manger, banking sector)

Lack of Innovation/Rigid Position There is a systematic refusal to any change or innovation by ERs, according to the managers. Respondents point out that ERs base their policies on courses of action from 20-30 years ago, which leads to very extreme and rigid positions that sometimes create conflicts between ERs and HR managers. The lack of innovation is linked to the ERs' lack of realism. However, respondents hope (and in some organizations this is already happening) that ERs and TUs will gradually realize that what they demand from organizations is very difficult to implement and that it actually does not make any sense. According to them, one solution is to renew people in these roles and, in order to do that, the work of an ER must be attractive.

I wish they were more realistic. To be more open to change. I wish they were not so focused on the collective agreement of the company. Because the company's agreement is completely decontextualized. (HR manager, transports' sector)

Lack of Competencies Concerning competencies, there is a general opinion that they should be improved. Overall, there is lack of leadership skills, ability to influence, negotiation skills, communication skills, general knowledge of the business and the organization, creative skills, sense of responsibility and initiative.

The industrial sector, for example, would like to see more representation and participation in other areas of the organization. This sector also pointed out that there is a lack of leadership competencies, but ERs feel that they are leaders and they feel powerful because they were chosen. The education sector is especially focused on the lack of participation of ERs (in this case, shop stewards), which is due to the lack of competencies, and is making efforts to create competent WCs. Regarding the public sector, there is the view that shop stewards only defend their members and use their position as a union delegate to avoid other work.

However, there is a widespread will across all the respondents to work with ERs who are competent and have ideas. Some of the HR managers that were interviewed said that there are some members of ERs that have some competencies and that it is easier to speak and negotiate with them. 


\subsubsection{Trust and Relationship among ERs and Management}

Positive Perception of the Role of ERs There is a widespread will among the respondents to work with competent ERs. This is mainly because all respondents have a positive perception of the role and importance of ERs, and almost all sectors have a positive relationship with the WC.

It is important to have someone who regardless of different ideological thinking is part of the company and is looking for solutions that enable internal harmony, (...) correcting situations that might be distorted by proposing balanced, sensible, timely solutions without threats (...) knowing that there are balances that are not easy to achieve. (HR manager, production sector)

The positive relationship that exists between HR managers and ERs (specially with WCs) is characterized by respect for the law and collective labor agreements; quite a close and trusting relation (however, some mistrust is always present); monthly meetings; direct contact to counter rumors and gossip; and there is true empathy concerning the employees' problems.

If we have a trust relationship with the unions, maybe we can do a better job, different things. But in fact... there is a relationship of trust with mistrust in the middle. (HR managers, production sector)

HR managers emphasize the importance that ERs have in the supervision and application of the workers' rights. Regarding WCs, there is the generalized opinion that they have a much broader vision, are more understanding and closer to the organization problems and the reality of the situation. However, HR managers would like to see more participation on the part of ERs when it comes to negotiations and believe that ERs could participate in joint projects to maintain the organization's sustainability.

HR managers have pointed out that it is healthy for organizations to have ERs that, regardless of ideological models of thought: are integrated in the organization and are looking for solutions that create a more harmonious working environment and that may rectify unfair situations by proposing solutions. Thus, they should cooperate in a balanced and sensible way, without threats and as part of the solution, knowing that there are equilibriums that are not easy to achieve.

\subsubsection{Labor Relations in Organizational Conflicts}

The qualitative results of this study showed that, in general, in the last two years, there were not many serious conflicts between management and ERs. There were, however, some small-scale conflicts and arguments (differing points of view), especially during the time of negotiations, where the ERs' ideological position that "the company does not give anything" comes more to the forefront. In the industrial sector, there was one organization that had a serious conflict which was resolved by communication, transparency and reaching an agreement. Showing, in this way, that trust and being transparent are ways of creating a better industrial climate. 
According to the respondents, instead of having a competitive position with the organization and always demanding more and more, TUs should be more concerned about maintaining the workers' jobs.

The collective agreement is favorable to workers even with no increase in wages for mandatory promotions. This causes some difficulties for banks. The unions understand this difficulty and seek to negotiate other social benefits such as support for families. Not only wage increases. The most important is to keep the jobs. (HR manager, banking sector)

In Portugal, the TU conflicts are now more directed to the government itself than to the organizations. It seems that unions and their shop stewards are now beginning to realize that companies do not have the capacity to respond to their requests, taking into consideration the crisis that the country is suffering.

At present, unions are almost forced to accept what companies offer them. They realize that there is no alternative. (HR manager, banking sector)

\subsection{Perception of HR Managers on ERs: Results from the Survey}

Results are presented based on the survey among 45 Portuguese HR managers of different sectors, compared to the score of 569 HR managers from 10 other countries in Europe (Belgium, Denmark, Estonia, France, Germany, Italy, The Netherlands, Poland, Spain and UK). We performed T-tests to analyze differences between Portuguese HR managers and all the others European HR manager. The significant differences between Portugal and the European mean have been circled in Fig. 10.1.

Figure 10.1 shows that Portuguese HR managers differ from their European colleagues in most of the studied variables. However, most of these differences go in the same direction.

Concerning the image of ERs, Portuguese HR managers perceive them as having less abilities $(\mathrm{M}=2.88$ in Portugal and $\mathrm{M}=3.14$ in Europe), benevolence $(\mathrm{M}=2.88$ in Portugal and $\mathrm{M}=3.35$ in Europe), and integrity $(\mathrm{M}=3.17$ in Portugal and $\mathrm{M}=3.47$ in Europe). This perception may also explain the empowerment of ERs by management that is lower in Portugal $(\mathrm{M}=3.16)$ than in Europe $(\mathrm{M}=3.61)$. To the Portuguese HR managers' organizational commitment of ERs is also relatively low.

Perceptions of the Portuguese HR managers are significant lower than those of European managers with the exception of task conflict $(\mathrm{M}=3.10$ in Portugal and $\mathrm{M}=2.81$ in Europe). In fact, among the Portuguese HR managers there is a perception of greater disagreements about ideas and viewpoints with ERs. However, the low levels of trust in industrial relations $(\mathrm{M}=2.89$ in Portugal and $\mathrm{M}=3.31$ in Europe) may compromise the potential benefits of task conflict. When we integrate these results it is evident the need to consider trust generation interventions with managers, unions and ERs representatives in order to avoid high risk of unintentionally triggering relationship conflict. 

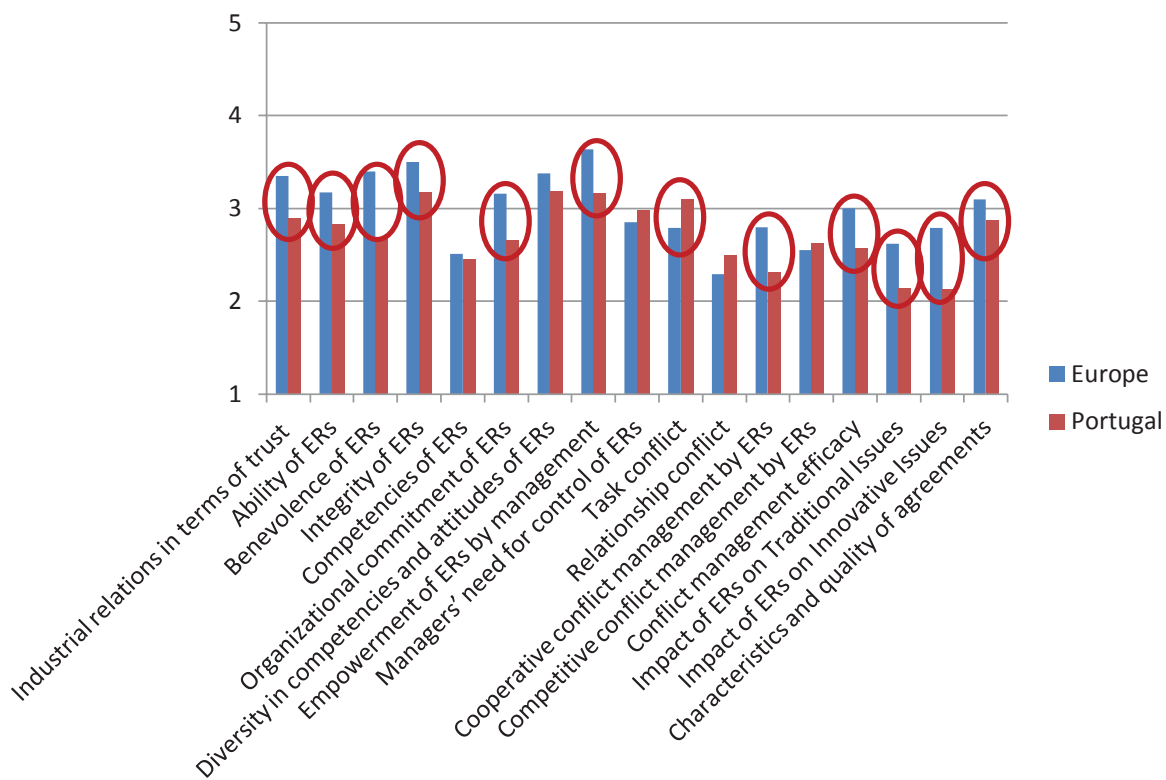

Fig. 10.1 Mean scores of main variables for Portuguese and European HR managers

The results suggest that in terms of conflict management strategies, Portuguese HR managers perceive that ERs use less cooperative conflict management approaches than the others European managers $(M=2.31$ in Portugal and $M=2.76$ in Europe). In fact, the absence of integrative strategies in the negotiation process may hinder win-win agreements and focus the discussion on the difference between parties.

Finally, the impact of ERs on traditional issues such as working hours or pay is lower in Portugal $(\mathrm{M}=2.14)$ than in Europe $(\mathrm{M}=2.65)$. The same pattern is found for the impact of ERs on innovative issues $(\mathrm{M}=2.13$ in Portugal and $\mathrm{M}=2.80$ in Europe). These results suggest that the overall impact of ERs is low which might be detrimental to the social dialogue.

\subsection{Suggestions Made by Employers to Improve Social Dialogue in Portugal}

Summarizing the results of this study, there is clearly a general opinion that ERs still have a very rigid and extreme position and that innovation and change is needed. This study also indicates that there is a distinction between the members of the WC and shop stewards. HR managers have the perception that the members of the WC are closer to the organization and more distant from politics and that shop stewards are the contrary. The more ideological the ERs are, the further away they are from 
the organization's financial reality. The respondents suggest renewing those in the role of shop stewards - with younger, more clear-minded people, who are more in touch with the social change which is occurring currently. At the same time, HR managers perceive a lack of competencies and knowledge which leads to a lack of participation and rigid, inflexible positions. Regarding the improvement of competencies, respondents proposed some training in the skills necessary for their role. However, there is, overall, a positive relationship between ERs and HR managers or, at least, an effort to create positive relations as the HR managers recognize the importance of having ERs. Regarding organizational conflicts, there are some small-scale conflicts that are due mostly to changes and the inflexible attitude of ERs.

Portuguese HR managers have made some suggestions to improve Social Dialogue that are summarized below:

More Open Attitude of ERs There is a general opinion that if ERs were more openminded and less rigid, different things could be done in organizations. ERs are still focused on protecting the workers too much, regardless if they are right or wrong, and ERs should have a more global view of an organization's sustainability. This is linked to being more realistic and more aware of the current economic reality, which could lead to agreements with a greater quality. Therefore, HR managers have referred to the fact that ERs must be aware of the changes in society that are taking place and that organizational change must happen too.

Improvement of Knowledge and Competencies As showed by the reports, HR managers believe that there is lack of competencies and lack of knowledge among ERs. On the one hand, HR managers have proposed the renewal of ERs - younger people with a clear mind. The replacement of the ERs would bring in younger people with more flexible views. To do this, the role of ERs must be attractive. Further, HR managers spoke about the importance of ERs being aware of the economic reality of the organization and knowing the organization that they are working at. HR managers also proposed training in global management competencies, communication competencies and training in social competencies, such as being polite. Overall, all HR managers pointed out that a WC should represent all the sectors of the company and manage common aspects for the employees.

Collective Bargaining According to the respondents, collective bargaining and workers' synchronization should be the most important thing in organizations. Respondents spoke about bringing shop stewards, members of the $\mathrm{WC}$ and unions to the negotiations. Most HR managers said that this model would allow the creation of joint projects and joint reflections that could be very important to an organization's growth.

Positive Climate for Industrial Relations As was said, all respondents have a positive and respectful relationship concerning ERs. Some of them even have a personal relationship with them. This relationship is characterized mostly by proximity. Respondents said that having a positive industrial climate is very important because it creates proximity with the workers, more focus in the organization and less recourse to strikes. 


\subsection{Discussion on the Expectations of Portuguese Employers Concerning the Roles, Attitudes and Competencies of ERs}

In recent years, industrial relations and social dialogue in Portugal are strongly influenced by economic austerity policies. This new reality questions the traditional role of trade unions and poses important challenges not only to Unions and ERs but also to HR mangers. In this study we were particularly interested in the HR managers view.

HRs have perceived that change is necessary in order to create more flexibility, employability, responsibility and more participation and dialogue within organizations. These results concur with those obtained by Munduate et al. (2012) where they analyzed the ERs' perception.

I think it's not a question of training. It is necessary to renew trade unions. We need younger people who are not contaminated by past practices. (HR manager, production sector)

There is a general perception among HR managers that unions are far from the current reality of organizations, namely drastic reduction in resources, substantial tax increases, and new legal constraints. The expectations that HRs have about ERs are low, mostly because of their generally rigid and inflexible positions. In HR managers view, ERs want to negotiate in the same way, with the same level of requirements, even when everything changed.

Over the past 2 years, we have had several changes. Changes which naturally affect the company. The social conflict within the company has essentially been through these changes. In the current context it does not make sense. But change is very difficult. And the conflict has primarily been for that reason. (HR manager, transports sector)

Nevertheless, HR managers want to involve ERs in collective bargaining and in joint projects to promote the sustainability of the organization. Simultaneously, ERs would also like to participate more in the strategy for the future of the organization. However, when both parties dialogue, there are still some small-scale conflicts and very different points of view.

Organizational change must also be taken. And we could not continue fixed to certain types of benefits that are comfortable, it is true, but they no longer make any sense. It's difficult to change. (HR manager, transports' sector)

The dialogue between the parties is still very much focused on the wages, impairing progress on the other matters. The collective bargaining ends up being a minimal negotiation, progressively disconnected from the reality of the company. However, HRs want to reinforce collective bargaining. ERs have to be able to pass from simply making demands, which always requires more and more rights, to a policy that combines demands, negotiation and partnership. Greater attention to maintaining jobs, rejecting conflict just for the sake of it and cooperation within an overall framework of competitiveness is necessary (Ferreira 2004). 
Usually there is an annual meeting where the union basically wants to know what is our position in terms of wages. That's basically it. (HR manager, production sector)

The participation of ERs in decisions and in the strategies of the organizations has to be assumed as a priority, using new processes, namely: establishment of a trusting relationship - a trusting relationship will encourage the sharing of information between parties. The parties have to assume and believe that negotiation will bring more benefits than competition; asking questions and providing information-one way of obtaining information between parties is to provide some indication of what each desires. Thereby, providing a sign for the other part to also provide some information about their preferences too; and present simultaneous proposals - the presentation of two or more proposals of equal value and including various items provides information about the preferences and interests of the parties (Simões 2013).

Finally, there is the question of the renewal of the frameworks in ERs that was referred to by the respondents. There is a problem of the representativeness among young workers. The respondents pointed out the need to make the work of an ERs attractive to young workers. In conclusion, as one of the respondents said, ERs are increasingly necessary to assure that economic progress is accompanied by social progress.

The results of this study clearly point out an emerging set of topics that Portugal will certainly need to address in the coming years to promote effective labor relations. These points do not arise only from the current economic crisis. The economic crisis has somehow accentuated the weaknesses in the actual social dialogue.

This is a time of change. This is a time to strengthen relations between ERs and employers to find innovative and flexible solutions that meet the needs of employees and employers. Portugal needs to increase its competitiveness, and we believe that it is rooted in organizations where the individual, group, managers, and unions dynamics influence their overall performance.

Open Access This chapter is distributed under the terms of the Creative Commons Attribution Noncommercial License, which permits any noncommercial use, distribution, and reproduction in any medium, provided the original author(s) and source are credited.

\section{References}

Dornelas, A., Ministro, A., Ribeiro, F., Cerdeira, M. P. G., Galego, P., \& Conduto, S. (2006). Livro verde sobre as relações laborais. Lisboa: Ministerio do Trabalho e da Solidariedade Social. [Green book about industrial relations].

Ferreira, A. C. (2004). Diálogo social: notas de reflexão a partir da experiência europeia e portuguesa. In E. Estanque, A. Ferreira, H. Costa, L. Mello, \& R. Veras (Eds.), Relações Laborais e sindicalismo em mudança: Portugal, Brasil e o contexto transnacional (pp. 75-97). Coimbra: Quarteto. [Social dialogue: reflections notes from the european and portuguese experience].

Munduate, L., Euwema, M., \& Elgoibar, P. (2012). Ten steps for empowering employee representatives in the new European industrial relations. Madrid: McGraw-Hill/Interamericana de España, S.L. 
Noronha, M. (1993). De 1993 até aos nosso dias [From 1993 until our days]. In M. Noronha (Ed.), Sindicalismo: Que futuro? (pp. 106-112). Lisboa: Clássica Ed.

Reinhard, N. (2013). Portugal: Industrial relations profile, EIRO. http://www.eurofound.europa. eu/eiro/country/portugal.

Rosa, E. (2011). O Estado a que Portugal chegou, por que chegou a ele, e como sair dele: Contributos para o debate nacional [The state to which Portugal has come, why he came, and how to get out of it: contributions to national debate].

Simões, E. (2013). Capítulo 7 - Negociar. In J. Neves, M. Garrido, \& E. Simões (Eds.), Manual de competências pessoais, interpessoais e instrumentais - teoria e prática (pp. 1-20). Lisboa: Sílabo. [Negotiate].

Stoleroff, A. (2000). Portugal: union development within the changing contexts of political economy and industrial relations. In J. Waddington \& R. Haffman (Eds.), Trade unions in Europe: facing challenges and searching for solutions (pp. 451-497). Brussels: ETUI. 